\title{
From Nature Tourism to Ecotourism: Assessing the Ecotourism Principles Fulfillment of Tourism Natural Areas in Bangka Belitung
}

\author{
Ibrahim Ibrahim ${ }^{1, *}$ (D) Nizwan Zukhri ${ }^{2}$ (D), Rendy Rendy ${ }^{1}$ (D), \\ ${ }^{1}$ Department of Political Science, Faculty of Social and Political Sciences, \\ University of Bangka Belitung, 33172, Bangka Belitung Islands Province, Indonesia \\ 2 Department of Management, Faculty of Economics, \\ University of Bangka Belitung, 33172, Bangka Belitung Islands Province, Indonesia \\ *Corresponding Author: iim_babel@yahoo.com
}

\section{ARTICLE INFO}

\section{Publication Info:}

Research Article

How to cite:

Ibrahim, I., Zukhri, N., E Rendy,

R. (2019). From Nature Tourism

to Ecotourism: Assessing the

Ecotourism Principles Fulfillment

of Tourism Natural Areas in

Bangka Belitung. Society, 7(2),

281-302.

DOI : 10.33019/society.v7i2.111

Copyright () 2019. Owned by Author(s), published by Society

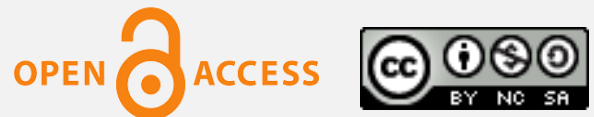

This is an open access article.

License: Attribution-

NonCommercial-ShareAlike (CC BY-NC-SA)

Received: November 1, 2019;

Accepted: December 15, 2019;

Published: December 31, 2019;

\begin{abstract}
Bangka Belitung is being transformed into a tourism destination area, relying on nature tourism. But unfortunately, the development of nature tourism does not include the development of ecotourism, even though these two things are interrelated. Nature tourism which is a mainstay of the tourism sector provides a very wide opportunity to strengthen ecotourism as part of the environmental movement in Bangka Belitung. This research aims to find out how the fulfillment of the ecotourism principles of tourism natural areas in Bangka Belitung Islands Province, Indonesia, and identifying unique things related to the application of these principles. Through quantitative research methods with a survey approach that is strengthened by field observations, this research found that assessed from 5 interval categories of the ecotourism principles fulfillment, $58 \%$ of the tourism areas in Bangka Belitung were included in the category of fulfilled of the ecotourism principles and $42 \%$ were in the strongly fulfilled category of the ecotourism principles. The research also found that although the application of each principle was met, there were unique and interesting notes on each principle.
\end{abstract}

Copyright (C) 2019. Owned by Author(s), published by Society. This is an open access article under CC-BY-NC-SA license. 


\section{Introduction}

Bangka Belitung is being transformed into a tourism destination area in the Sumatra region. The tourism sector is being managed as an alternative economic sector for this region (see Wardhani \& Valeriani, 2016; Valeriani, 2010). The growth of domestic tourist arrivals in the past decade, hotel occupancy, and the number of foreign tourists (Badan Pusat Statistik Provinsi Kepulauan Bangka Belitung, 2018) and an increasing number of new hotel units (Badan Pusat Statistik Provinsi Kepulauan Bangka Belitung, 2017) as the most basic indicator to measure the growth of tourism sector in Bangka Belitung. The popularity of the Novel Laskar Pelangi (Rainbow Troops), which is a best-selling novel, and 2008's award-winning movie 'Laskar Pelangi' are the trigger factors of the growth of tourism sector in Bangka Belitung. The Government of the Bangka Belitung Islands Province, at the time of Governor Eko Maulana Ali (2007 - 2013), had planned the "Visit Babel Archi 2010" which then became the integrated process to drive the tourism development program in Bangka Belitung. The tourism development policy was then continued by his successor, until now, even though the concept of "Visit Babel Archi 2010" has passed.

The main tourism in Bangka Belitung is nature tourism. As an island province, Bangka Belitung has many white sandy beaches. It attracts tourists to visit Bangka Belitung. Beaches, islands, coastal areas and coral reefs are the mainstays of tourism spots in Bangka Belitung. Ibrahim et al., (2019) showed that most of the tourism destinations in Bangka Belitung that were most popularly chosen by outside tourists were natural tourism areas. It affirms that natural areas are the main destination for tourism in Bangka Belitung. Indeed, several non-nature tourism areas are other tourist attractions such as replicas of the Laskar Pelangi School, the Museum of Kata, and Puri Tri Agung Pagoda, but generally, beaches and islands are the main tourism that tourists want to visit.

The growing tourists visit is an important momentum for promoting environmental values. It is very important for the development of tourism that relies on uniqueness and natural beauty. The tourists not only come to enjoy the tourism areas in Bangka Belitung but also have the opportunity to engage in the process of environmental preservation as well as a medium to increase the movement of environmentally-oriented. The ecotourism concept is an important essence as an integral part of tourism potential development. It recently became a trend along with the implementation of tourism and the environment as a unified interconnected activity and touristic.

This condition raises interesting questions about how the ecotourism principles are implemented in tourism areas in Bangka Belitung. Nature tourism and ecotourism have different concepts. Nature tourism relies solely on nature, while ecotourism is more in the context of the environmental movement's promotion. Wood (2002: 7) said that ecotourism grows and develops as a new large industry, which has great potential as a tool to promote the principles of sustainable development (Bratasida, 2002; Hundloe, 2002). According to Wall (1997: 483), ecotourism refers to three main aspects, namely economics, ecology, and culture (Dalem, 2002). Several other experts define ecotourism as tourism that responsible for natural areas preservation, provide economic benefits, maintain cultural integrity for the community, and very related with conservation principles (Nugroho et al., 2018; Damanik, 2006; Fandeli, 2002; Hill \& Gale, 2009: 3-16).

Development of ecotourism may not have been managed and planned properly, however, Bangka Belitung has existing conditions that enable the ecotourism principles to be run and implemented. While the growth of the tourism sector in Bangka Belitung, which is based on nature tourism, is on the rise, the ecotourism development as part of the combination of natural 
tourism and promotion of environmental issues is an interesting subject. This research explored how the Ecotourism Principles Fulfillment of Tourism Natural Areas in Bangka Belitung and identify interesting aspects of the application of these principles.

\section{Literature Review}

The ecotourism concept is different from the tourism concept which is commonly known as a trip to relax the mind and explore new things. Although it began based on nature tourism, the idea of ecotourism developed more visionary that refers to environmental issues. Ecotourism commences with ideas and views about the needs and efforts to preserve the environment, without having to be carried out systematically and organized, in an activity known as conservation, as an integrated whole of activities. Butarbutar \& Sumarno (2013: 98) and Nofiarli (2018) indeed said that ecotourism is very close to environmental principles. Chairiyah (2013) said that ecotourism is based on sustainability.

At least there are 4 things connectedness between tourism and the environment according to Buckley (1994: 661): 1) natural environment component as a performance base or as a product, 2) tourism management to reduce the impact of environmental damage, 3) the tourism contribution to environmental conservation, both directly and indirectly, and 4) the tourist attitude in preserving environment. Therefore Buckley said that there are environmental aspects in every tourism business, namely products and markets, management, money, and tourists. Here are the ecotourism frameworks according to Buckley:

Figure 1

Ecotourism Framework according to Buckley

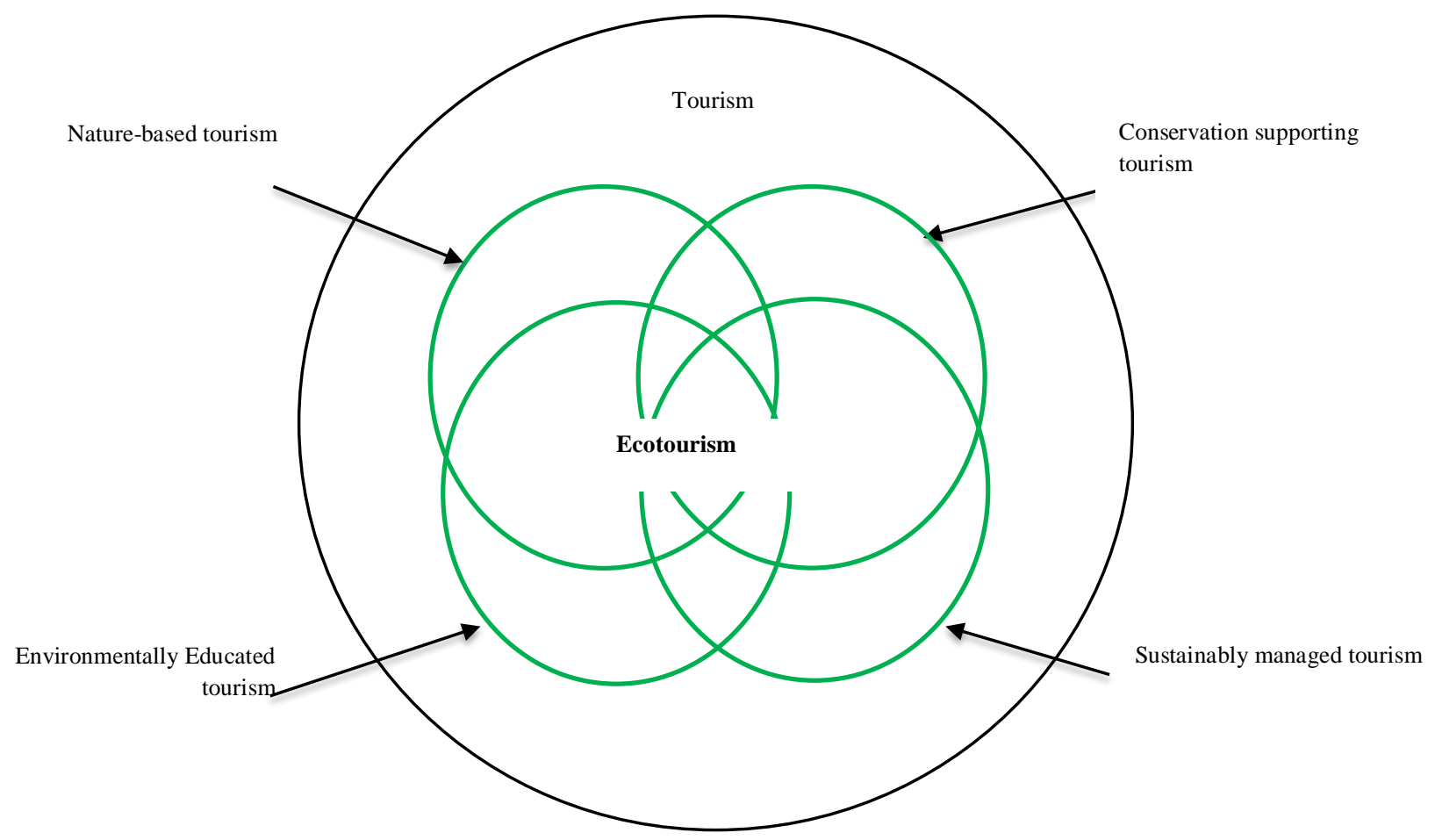

Source: (Buckley, 1994) 
Buckley (2009) also explained that ecotourism is related to the following terms and products:

Table 1

Related Terms and Ecotourism Products

\begin{tabular}{|l|l|}
\hline Terms & Products \\
\hline Green tourism & Nature-based \\
Alternative tourism & Wildlife \\
Endemic tourism & Adventure \\
Geological tourism & Cultural \\
Geographical tourism & Adventure-culture-ecotourism \\
Responsible tourism & Nature, eco-and advance tourism \\
Sustainable tourism & Outdoor \\
\hline
\end{tabular}

Source: (Buckley, 2009)

Meanwhile, Wood (2002) said that the root of ecotourism was the conservation movement through income strategies in areas that require preservation. Ecotourism commences with ideas from people who want to participate in environmental conservation extensively. Wood noted that in the early 1980s, many communities began to utilize various conservation areas to be introduced to the public. Camping, hiking, and various other outdoor activities were conceived along with environmental preservation values that accompanied the trips of the tourists in exploring the nature tourism area. According to Wood, ecotourism is a promising business, but still, the social and environmental affairs are the main target and therefore it takes a commitment to ensure the ecotourism principles fulfillment when using the term Ecotourism.

The ecotourism principles according to Wood (2002: 14) at least rest on several things. Reducing the negative impact on nature and culture that could ruin tourism destinations is an important principle, as well as efforts to educate tourists on conservation urgency. Safitri \& Putra (2018) said that environmental education in ecotourism aims to encourage environmental awareness. Another thing according to Wood, the principles are the emphasis on business responsibilities involving residents and local governments with mutual benefit, direct income from nature and conservation management for the tourism areas preservation, emphasizing economic benefits to local communities, the environmentally-oriented tourism areas development, and emphasize aspects that do not spoil the tourism destination. Holden (2008: 234) described ecotourism dimensions as follows: 
From Nature Tourism to Ecotourism:

Assessing the Ecotourism Principles Fulfillment of Tourism Natural Areas in Bangka Belitung

Table 2

Dimensions of Ecotourism

\begin{tabular}{|c|c|c|}
\hline No. & Dimensions & Interpretations \\
\hline 1 & Activity & Experience-based tourism on natural and cultural resources. \\
\hline 2 & Business & Tourism management provides ecotourism tours. \\
\hline 3 & Philosophy & Care and respect for land, nature, community, and culture \\
\hline 4 & Strategy & $\begin{array}{l}\text { A tool for conservation, economic development, and cultural } \\
\text { revival. }\end{array}$ \\
\hline 5 & Marketing Device & Promote tourism by emphasizing environmental aspects \\
\hline 6 & Management & $\begin{array}{l}\text { Responsible management, low negative impacts, green tourism, } \\
\text { etc. }\end{array}$ \\
\hline 7 & Symbol & A debate between tourism and the environment. \\
\hline 8 & Principles and Goals & $\begin{array}{l}\text { Sustainable and mutually beneficial relationships between } \\
\text { tourism and the environment }\end{array}$ \\
\hline
\end{tabular}

Source: (Holden, 2008)

Based on several theoretical descriptions above, ecotourism is a combination of tourism principles and environmental sustainability principles. This means it is important to pay attention to how environmental contexts are implemented in the tourism industry. Tourism is not just a business affair and an exchange between pleasure and facilities provided by the tourism management, but more than that it includes broader dimensions. Based on the above study, this research formulates relevant ecotourism principles. These principles are environmental conservation practices, efforts to encourage tourist's concern for the environment, attractions that include exploratory environmental experiences, green tourism practices by tourism management, impact of tourism areas development on the environment, tourist vulnerability, consumption on non-renewable commodities, control and support development from external parties, and the empowerment of local community. In detail, the principles are described as follows:

Table 3

The Ecotourism Principles Fulfillment

\begin{tabular}{lll}
\hline No. & \multicolumn{1}{c}{ Principles } & \multicolumn{1}{c}{ Fulfillments } \\
\hline 1 & $\begin{array}{l}\text { Environmental conservation } \\
\text { Practices }\end{array}$ & $\begin{array}{l}\text { Conservation practices for tourism areas such as } \\
\text { green areas, breeding areas, and others. } \\
\text { Tourists are invited or encouraged to care about the } \\
\text { environment, tourism areas management encourage } \\
\text { tourist to care and interested in efforts to } \\
\text { environmental conservation. } \\
\text { Encourage tourists concern for }\end{array}$ \\
$\begin{array}{ll}\text { Attractions that include } \\
\text { exploratory environmental } \\
\text { experiences }\end{array}$ & $\begin{array}{l}\text { The unique events/performances/explorations that } \\
\text { directly involve tourists to the environment } \\
\text { preservation, such as diving, snorkeling, cruising by } \\
\text { boat, and others. }\end{array}$
\end{tabular}

Copyright ( 2019. Owned by Author(s), published by Society. This is an open access article under CC-BY-NC-SA license. https://doi.org/10.33019/society.v7i2.111

285 
From Nature Tourism to Ecotourism:

Assessing the Ecotourism Principles Fulfillment of Tourism Natural Areas in Bangka Belitung

\begin{tabular}{lll}
\hline No. & \multicolumn{1}{c}{ Principles } & \multicolumn{1}{c}{ Fulfillments } \\
\hline 4 & $\begin{array}{l}\text { Tourism management practices green tourism, for } \\
\text { tourism management } \\
\text { example educating tourists to dispose of rubbish in } \\
\text { trash bins, properly managed waste, tourism areas } \\
\text { neatly arranged and clean, not barren, and using } \\
\text { equipment that does not damage the environment, } \\
\text { and others. }\end{array}$ \\
5 & $\begin{array}{l}\text { Impact of tourism area } \\
\text { development on the } \\
\text { environment }\end{array}$ & $\begin{array}{l}\text { Tourism areas development is not potentially } \\
\text { damaging the environment; development is expected } \\
\text { not to be negative for the environment. }\end{array}$ \\
6 & $\begin{array}{l}\text { The tourism area has maximum security for the } \\
\text { safety of tourists, in terms of crime, preventing } \\
\text { incidents/potential incidents that make tourists } \\
\text { uncomfortable. }\end{array}$ \\
7 & $\begin{array}{l}\text { Coth tourists and tourism management do not use } \\
\text { non-renewable commodities, such as fossil energy, } \\
\text { renewable commodities }\end{array}$ \\
non-environmentally oriented foodstuffs, and others.
\end{tabular}

\section{Research Methodology}

The results of this study were obtained with a quantitative descriptive approach that uses surveys as data collection techniques. To enrich data analysis, researchers conducted observations and interviews. The selected research location is the popular tourist areas that rely on nature tourism in Bangka Island and Belitung Island. The selected locations in Bangka Islands were Pesona Beach, Parai Beach, Tongachi Beach, Pasir Padi Beach, Tikus Emas Beach, and Kolong Biru, while the selected locations in Belitung Island were Tanjung Tinggi Beach, Tanjung Kelayang Beach, Garuda Island Region, Lengkuas Island, Bukit Perahu Beach, and Burung Mandi Beach. Respondents were determined based on quota sampling principles with certain criteria; 1) tourists from outside Bangka Belitung, 2) tourists have been at least 60 minutes at the tourism area, and 3) one respondent selected in each tourist group. The number of quota respondents was determined by consideration of tourism destination popularity, as follows: 
From Nature Tourism to Ecotourism:

Assessing the Ecotourism Principles Fulfillment of Tourism Natural Areas in Bangka Belitung

Table 4

Sample Quota

\begin{tabular}{|l|c|l|c|}
\hline \multicolumn{2}{|c|}{ Bangka } & \multicolumn{2}{c|}{ Belitung } \\
\hline \multicolumn{1}{|c|}{ Location } & Quota & \multicolumn{1}{c|}{ Location } & Quota \\
\hline Parai beach & 5 & Burung beach & 5 \\
\hline Pesona beach & 5 & Bukit Perahu beach & 5 \\
\hline Tikus Emas beach & 5 & Garuda isle & 6 \\
\hline Tongachi beach & 5 & Tanjung Kelayang & 6 \\
\hline Kolong Biru & 5 & Tanjung Tinggi & 7 \\
\hline Pasir Padi beach & 5 & Lengkuas Island & 6 \\
\hline \multicolumn{1}{|c|}{ Total } & 30 & \multicolumn{1}{c|}{ Total } & 35 \\
\hline \multicolumn{2}{|c|}{ Total of 65 Respondents } \\
\hline
\end{tabular}

The assessment of ecotourism principles was conducted by asking questions according to nine basic ecotourism principles, as follows: 1) environmental conservation practices, 2) efforts to encourage tourist's concern for the environment, 3) attractions that include exploratory environmental experiences, 4) green tourism practices by tourism management, 5) impact of tourism areas development on the environment, 6) tourist vulnerability, 7) consumption on non-renewable commodities, 8) control and support development from external parties, and 9) the empowerment of local community. Respondents, according to predetermined criteria, are asked to provide measurements by their perceptions. Measurement of ecotourism principles using the scoring system; the maximum value for each principle is 1 . The questions are arranged in a checklist divided into 5 options, including:

\begin{tabular}{l|c|} 
Category & Score \\
\hline Not at all & 0 \\
Very little & 0,25 \\
Somewhat & 0,5 \\
Extended but not optimal & 0,75 \\
Fulfillment & 1
\end{tabular}

Furthermore, the total score was categorized into five intervals as follows: 
From Nature Tourism to Ecotourism:

Assessing the Ecotourism Principles Fulfillment of Tourism Natural Areas in Bangka Belitung

Fulfillment

\begin{tabular}{l|l}
$00-1,8$ & Unfulfilled \\
$1,9-3,6$ & Less fulfilled \\
$3,7-5,4$ & Moderate \\
$5,5-7,2$ & Fulfilled \\
$7,3-9,0$ & Strongly fulfilled
\end{tabular}

To enrich the data in the analysis, the observations were conducted on each question raised at all locations. Interview with tourism management, the person in charge of tourism business involved in tourism management, and the local community around the tourism areas were also conducted to strengthen the analysis.

\section{Results and Discussion}

\section{A. Tourism Areas in Bangka Island}

The tourism areas scoring in Bangka Island based on the survey data results to assess the ecotourism principles fulfillment as follows:

Figure 2

The Ecotourism Principles Fulfillment Score in Bangka Island

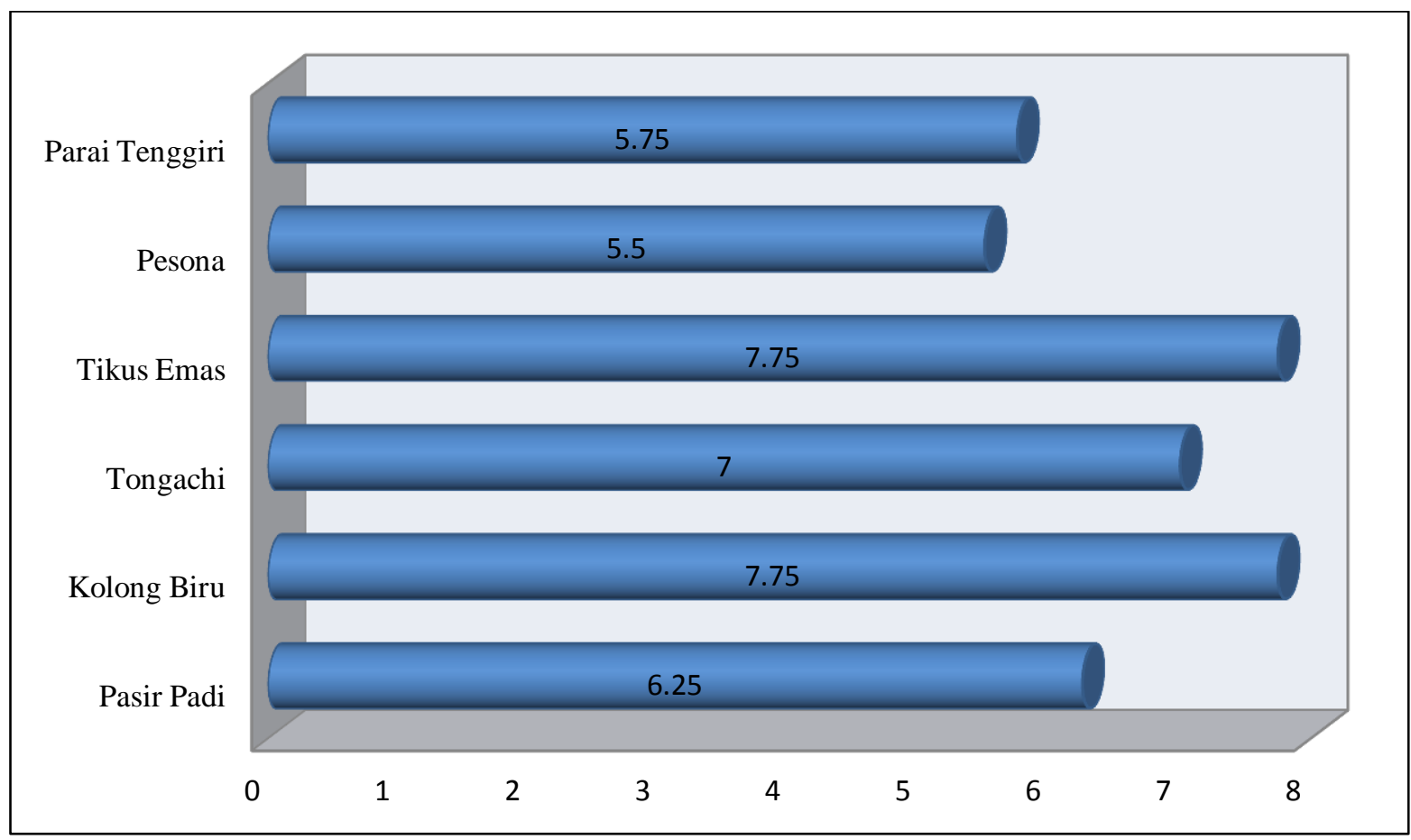

Source: (Primary Data, 2019)

Copyright (C) 2019. Owned by Author(s), published by Society. This is an open access article under CC-BY-NC-SA license. https://doi.org/10.33019/society.v7i2.111 


\section{Parai Tenggiri Beach}

Based on the data as shown in figure 2, Parai Tenggiri Beach scored 5.75 out of 9 total scores as the maximum value (fulfilled category). Assessed based on the ecotourism principles, the results as follows:

1) Environmental conservation Practices. Parai Tenggiri Beach has green areas such as mini garden and garden at the entrance and around the hotel rooms.

2) Encourage tourist's concern for the environment. It is difficult to find encouraged to care about the environment around the beach to fulfill the principle of environmental awareness, although there are already rules for activities around the beach.

3) Attractions that include exploratory environmental experiences. The attractions presented were more to watersport games, not classified as attractions that can increase environmental awareness.

4) Green tourism practices by tourism management. The management is quite good at managing the green tourism practice, but it has been found that there is a wastewater pipe that flows from the tourism area to the beach.

5) Impact of tourism area development on the environment. The development of the tourism area on Parai Tenggiri Beach is already good and it's expected not to have an impact on the environment.

6) Tourist vulnerability. The management has put up instructions and rules around the beach. The coast guard is also available, though not reaching all areas.

7) Consumption of non-renewable commodities. It has found a lot of non-organic waste scattered around the beach.

8) Control and support development from external parties. It is limited considering Parai Tenggiri Beach is an area that has been fully managed by the private sector.

9) Empowerment of the local community. It also lacks empowering the local community considering Parai Tenggiri Beach is an area that has been fully managed by the private sector.

\section{Tanjung Pesona Beach}

There is no difference between the Tanjung Pesona Beach and the Parai Tenggiri Beach, which is also a privately managed tourism area and as an open public tourism destination. Both of them also manage hotels and the beach area. Based on the data as shown in figure 2, Tanjung Pesona Beach scored 5.5 from a total of 9 (fulfilled category). Assessed based on the ecotourism principles, the results as follows:

1) Environmental conservation Practices. There is no conservation area, but there are green areas like Ocean Park which are relatively poorly managed. There are several parks designed to beautify the tourism areas.

2) Encourage tourist's concern for the environment. It is difficult to find encouraged to care about the environment around the beach to fulfill the principle of environmental awareness, although there are already rules for activities around the beach.

3) Attractions that include exploratory environmental experiences. Some exploratory environmental experiences do not run optimally.

4) Green tourism practices by tourism management. The management has not been optimal to educate tourists to keep the environment clean.

5) Impact of tourism area development on the environment. The development of the tourism area on Tanjung Pesona Beach is already good and it's expected not to have an impact on the environment. 
6) Tourist vulnerability. The management has put up instructions and rules around the beach. The coast guard is not available.

7) Consumption of non-renewable commodities. The management has provided trash bins, but it has found a lot of non-organic waste scattered around the coast.

8) Control and support development from external parties. It is limited considering Tanjung Pesona Beach is an area that has been fully managed by the private sector.

9) Empowerment of the local community. It also lacks empowering the local community considering Tanjung Pesona Beach is an area that has been fully managed by the private sector.

\section{Tikus Emas Beach}

Located in the Bangka Regency, Tikus Emas Beach is a newly developed tourism area and not too far away with Parai Tenggiri Beach and Tanjung Pesona Beach. As a new tourism destination, Tikus Emas Beach attracts many tourists because it is considered to present a new tourism atmosphere. Based on the data as shown in figure 2, Tikus Emas Beach scored 7.57 from a total of 9 (strongly fulfilled category). Assessed based on the ecotourism principles, the results as follows:

1) Environmental conservation Practices. There are conservation practices in Tikus Emas Beach, which consist of turtle breeding (turtle breeding and also adult turtle breeding) which can be seen directly by tourists. There is a conservation area designed as a photo spot.

2) Encourage tourist's concern for the environment. Some many appeals and rules encourage tourists to care about the environment and cleanliness of the beach.

3) Attractions that include exploratory environmental experiences. Explorative facilities are also provided by the management, such as flying fox, All-Terrain Vehicle (ATV) motorbike to go around the beach, and water sports games.

4) Green tourism practices by tourism management. The beach cleanliness is very good; there is also prohibition for burning activities in this area.

5) Impact of tourism area development on the environment. The development of the tourism area on Tikus Emas Beach is already good and it's expected not to have an impact on the environment. Although not far from the shore it can be seen that the Suction Dredger (KIP) is still operating. This coastal area is an offshore tin mining production area as the Bangka Belitung is known as tin-production areas (Erman, 2017; Ibrahim et al., 2017; Susilo \& Maemunah, 2009).

6) Tourist vulnerability. The management has set up a coast guard to monitor tourist activity.

7) Consumption of non-renewable commodities. Food consumption is dominated by fast food and snacks that produce plastic waste, but the management has managed garbage and waste properly.

8) Control and support development from external parties. The management has coordinated with related parties.

9) Empowerment of the local community. The involvement of the local community is still limited. This can be seen from the lack of workers from the local community.

\section{Tongachi Beach}

Located in the Bangka Regency, Tongachi Beach is popular as a new tourism destination developed in recent years. It is a must-visit tourism area that presents a unique experience through the exploration of beautiful beaches with more attractions compared to other tourism 
areas. Based on the data as shown in figure 2, Tongachi Beach scored 7 from a total of 9 (fulfilled category). Assessed based on the ecotourism principles, the results as follows:

1) Environmental conservation Practices. There are conservation practices in Tongachi Beach, which consist of turtle breeding and the presence of water break (large stones piled on the edge of the beach). Turtle breeding is located in captive ponds and in coastal areas that have been protected by water breaks.

2) Encourage tourist's concern for the environment. The management invites tourists to preserve the environment through written appeals at various points.

3) Attractions that include exploratory environmental experiences. The management presents explorative attraction activities such as diving, boat cruising, and cultural events. It also provides a library area and ethnic buildings.

4) Green tourism practices by tourism management. The management provides an environmentally-oriented atmosphere. The Tongachi Beach area is clean and tidy.

5) Impact of tourism area development on the environment. The development of the tourism area on Tongachi Beach is already good and it's expected not to have an impact on the environment. Although it is still seen offshore tin mining by tin mining companies.

6) Tourist vulnerability. The safety and comfort of tourists are well anticipated by the management.

7) Consumption of non-renewable commodities. There are quite several food stalls with various food and beverage menus that still use plastic containers.

8) Control and support development from external parties. The management coordinates cultural events with external parties. It is limited considering Tongachi Beach is an area that has been fully managed by the private sector.

9) Empowerment of the local community. Tongachi Beach seems to be less empowering the local community. There are restrictions on selling areas.

\section{Kolong Biru}

Kolong Biru is a pond of water, caused by tin mining activity, which is located in the central Bangka District and on the border with South Bangka Regency. Kolong Biru is called so because Kolong Biru has clear and blue color water. It is known as a tourism area that offers beautiful scenery for photography. Kolong Biru has been explored in recent years and quickly gaining popularity through social media. Based on the data as shown in figure 2, Kolong Biru scored 7.75 from a total of 9 (strongly fulfilled category). Assessed based on the ecotourism principles, the results as follows:

1) Environmental conservation Practices. Kolong Biru is an open and barren area because it was an ex-tin mining location but already started planting trees to reduce barrenness.

2) Encourage tourist's concern for the environment. The management invites tourists to preserve the environment through written appeals at various points with persuasive language and the millennial style.

3) Attractions that include exploratory environmental experiences. Ex-tin mining tourism has not yet been fully developed, only relying on the beauty of the blue water. The management began to provide water bikes to explore the beauty of the blue water.

4) Green tourism practices by tourism management. It's already categorized as a clean and tidy area and well-managed by the community.

5) Impact of tourism area development on the environment. The development of the tourism area on Kolong Biru is already good and it's expected not to have an impact on the environment. Although it was an ex-tin mining location. 
6) Tourist vulnerability. There is a potential concern for tourist safety because of the limited safety fence.

7) Consumption of non-renewable commodities. Residents provide small stalls with a variety of local snacks. Cleanliness is always maintained by the management.

8) Control and support development from external parties. Kolong Biru tourism area is managed by the local government through its village. The local community is fully involved.

9) Empowerment of the local community. The development of the Kolong Biru tourism area strengthens support for local communities and gives direct benefits to residents.

\section{Pasir Padi Beach}

Pasir Padi Beach is located in the City of Pangkal Pinang, the capital city of the Bangka Belitung Islands Province, and only about 15 minutes away by a four-wheeled vehicle from Depati Amir Airport. Pasir Padi Beach is managed by the government and the only coastal area in the City of Pangkal Pinang. Although less popular than other beaches, it is the most-visited beach because of its location not far from the city center. Based on the data as shown in figure 2, Pasir Padi Beach scored 6.25 from a total of 9 (fulfilled category). Assessed based on the ecotourism principles, the results as follows:

1) Environmental conservation Practices. There has not been much conservation in the Pasir Padi Beach area, but in some areas, tree planting has been carried out for reforestation and installation of stones as a breakwater in the beach area to resist abrasion.

2) Encourage tourist's concern for the environment. There are signposts to encourage tourists to care and preserve the environment.

3) Attractions that include exploratory environmental experiences. There are no adequate facilities to provide an explorative tourist experience. There are only ATV motorbikes for rent.

4) Green tourism practices by tourism management. The arrangement of the beach is still chaotic with the unarranged vendors. Garbage is scattered everywhere even though the management has provided trash bins.

5) Impact of tourism area development on the environment. The development of the tourism area on Pasir Padi Beach is already good and it's expected not to have an impact on the environment besides the problem of threatening abrasion. The constructions of meeting rooms and new hotels, as well as swimming pools on the beach, are other developments that are considered as additional beach facilities.

6) Tourist vulnerability. The management cooperates with the police to provide a tourism police post.

7) Consumption of non-renewable commodities. Tourists have not fully applied the principle of environmentally-oriented.

8) Control and support development from external parties. Pasir Padi Beach tourism area involves many components where the government as its management.

9) Empowerment of the local community. Many communities are involved in the activities of the Pasir Padi Beach tourism area, as sellers or for other services. Economically, it is a great benefit for the local community although some businesses are privately owned.

\section{B. Tourism Areas in Belitung Island}

The tourism areas scoring in Bangka Island based on the survey data results to assess the ecotourism principles fulfillment as follows: 
Figure 3

The Ecotourism Principles Fulfillment Score in Belitung Island

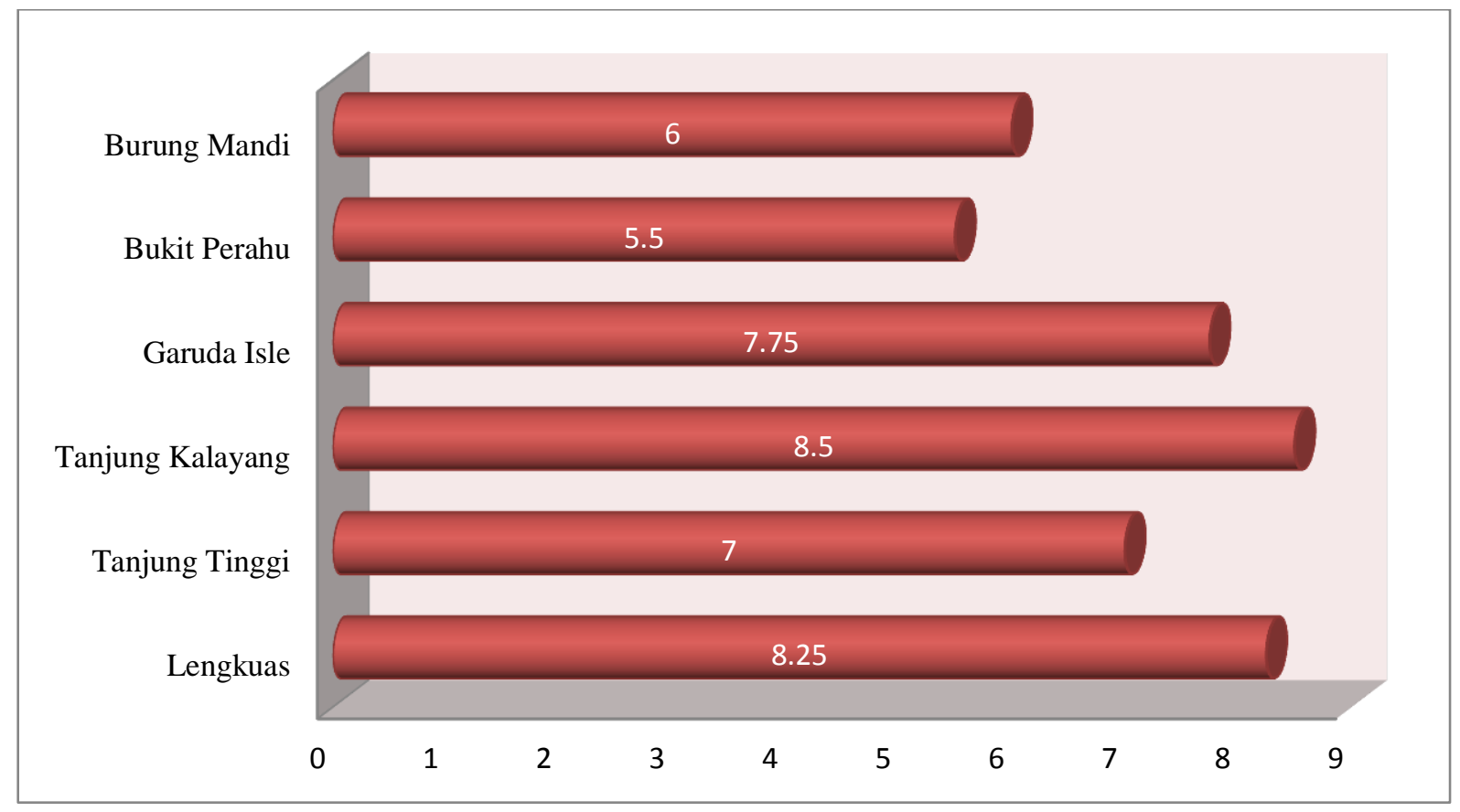

Source: (Primary Data, 2019)

Based on the data as shown in figure 3, the highest score of the ecotourism principles fulfillment is 8.5 , while the lowest score is 5.5.

\section{Burung Mandi Beach}

Burung Mandi Beach is a coastal area located in East Belitung regency and its residents generally are fishermen. Burung Mandi Beach is famous for its sloping beaches and distinctive boats used by fishermen to sea. Based on the data as shown in figure 3, Burung Mandi Beach scored 6 from a total of 9 (fulfilled category). Assessed based on the ecotourism principles, the results as follows:

1) Environmental conservation Practices. There is no conservation in the Burung Mandi Beach area, although it is mentioned on one of the announcement boards that there are endemic birds in this area.

2) Encourage tourist's concern for the environment. There are no signposts to encourage tourists to care and preserve the environment. There are only appeals for not ride the boat in a coastal area.

3) Attractions that include exploratory environmental experiences. The tourists can only see the fishing boats in the coastal area. The boats are only used for fishing by the fishermen and not for coastal exploration activities.

4) Green tourism practices by tourism management. There are trash bins in several areas on the beach and an appeal to dispose of garbage in the trash bins.

5) Impact of tourism area development on the environment. The development of the tourism area on Burung Mandi Beach is already good and it's expected not to have an impact on the environment. 
6) Tourist vulnerability. There is a prohibition to swimming on the beach, but there are no guards.

7) Consumption of non-renewable commodities. There is still much plastic waste scattered in the beach area.

8) Control and support development from external parties. Burung Mandi Beach is managed by the local community and the involvement of local government is fairly intensive. Information boards and infrastructure improvements are assisted by the local government.

9) Empowerment of the local community. The empowerment of the local community is running well. Local community involved to sell and exhibit the work of local specialties.

\section{Bukit Perahu Beach}

Bukit Perahu Beach located in Belitung Regency. It is located in the hilly area with a beautiful view. It takes approximately 45 minutes from the center of Tanjung Pandan City to reach this area. Based on the data as shown in figure 3, Bukit Perahu Beach scored 5.5 from a total of 9 (fulfilled category). Assessed based on the ecotourism principles, the results as follows:

1) Environmental conservation Practices. There are no specific conservation practices in this tourist area, but at the entrance to the beach, there is a greening area planted to beautify the beach area.

2) Encourage tourist's concern for the environment. There are no signposts to encourage tourists to care and preserve the environment.

3) Attractions that include exploratory environmental experiences. There are no attractions but provided special cottages located on the shoreline. This cottage is interesting because it was built with a traditional design and placed on the sidelines of a tree on the beach. Other facilities are the availability of a swimming pool built with a view overlooking the beach. The swimming pool was built right on the side of the hill so it becomes an attractive selfie location with a background of the open sea.

4) Green tourism practices by tourism management. There is no specific appeal for managing waste for tourists but the area is neat and clean.

5) Impact of tourism area development on the environment. The development of the tourism area on Bukit Perahu Beach is already good and it's expected not to have an impact on the environment. But the construction of the cottage on the beach is very potentially affecting the environmental support in the coastal area.

6) Tourist vulnerability. Special supervision from adult family members is required for children as the area is hilly. Although the fence is provided along the hill, tourists must be careful. Pantai Bukit Perahu is not as popular as other beaches in Belitung Island, but the privacy of tourists is maintained because the area is secluded with a hilly location.

7) Consumption of non-renewable commodities. With the availability of restaurants, the use of plastic for consumption purposes is well managed.

8) Control and support development from external parties. As an area managed privately, government control and external communities are limited.

9) Empowerment of the local community. The owner employs residents as employees. The existence of this tourism area provides benefits for residents.

\section{Garuda Isle}

Garuda Isle is a tourism destination that is widely mentioned by tourists and included in the favorite category. It is a small island that has a large rock resembling the head of Garuda (a 
legendary bird as the emblem of Indonesia). Tourist activities at Garuda Isle are usually accompanied by exploring the surrounding area, consisting of small rocky islands. Garuda isle can be reached by sea and located opposite Tanjung Kelayang Beach. The assessment of Garuda isle depends on the assessment of Tanjung Kelayang Beach considering that Garuda isle is usually visited from Tanjung Kelayang Beach. Based on the data as shown in figure 3, Garuda isle scored 7.75 from a total of 9 (strongly fulfilled category). Assessed based on the ecotourism principles, the results as follows:

1) Environmental conservation Practices. Garuda Isle is a location for releasing sea turtles captive to the sea. Even though it is a small and rocky island, this island will be surrounded by sandy plains during low tide.

2) Encourage tourist's concern for the environment. There are signposts to encourage tourists to care and preserve the environment.

3) Attractions that include exploratory environmental experiences. There are exploratory activities through island cruising using boats managed by local fishermen.

4) Green tourism practices by tourism management. The management invites tourists to keep the cleanliness of the island and the sea from the trash. Boats usually provide a trash bin.

5) Impact of tourism area development on the environment. The development of Garuda Isle maintains the natural aspect; there is no construction of facilities on Garuda Isle.

6) Tourist vulnerability. Tourists are equipped with safety buoys. As an area close to the shoreline, Garuda Island is quite safe.

7) Consumption of non-renewable commodities. Unfortunately, to reach Garuda Isle, boats with diesel fuel are still the main transportation.

8) Control and support development from external parties. This area is managed by the community and managed jointly by residents.

9) Empowerment of the local community. The empowerment of the local community is running well. The local community benefits from this tourism area.

\section{Tanjung Kelayang Beach}

Tanjung Kelayang Beach is located in Belitung Regency. It takes approximately 45 minutes from the center of Tanjung Pandan City to reach this area. Tanjung Kelayang Beach is popular not only because of the beauty of its beach but also as a transit point to go to several other tourism destinations. Based on the data as shown in figure 3, Tanjung Kelayang Beach scored 8.5 from a total of 9 (strongly fulfilled category). Assessed based on the ecotourism principles, the results as follows:

1) Environmental conservation Practices. The principle of conservation works well at Tanjung Kelayang Beach, which consists of turtle breeding and coral transplantation. This conservation itself is managed by the local community.

2) Encourage tourist's concern for the environment. Tourists are invited to care for the environment through various persuasive signposts.

3) Attractions that include exploratory environmental experiences. Management provides explorative experiences for tourists through island cruising activities.

4) Green tourism practices by tourism management. The management invites tourists to keep cleanliness and dispose of trash in the trash bins. Even tourists are encouraged to bring their own trash home.

5) Impact of tourism area development on the environment. The development of the Tanjung Kelayang Beach area is not destructive to the environment. The tourism area was developed into a meeting center by building a large meeting hall for event activities. 
6) Tourist vulnerability. For the safety and convenience of tourists, the management has set provisions for the use of safety equipment for tourists who will continue their tour to other challenging places.

7) Consumption of non-renewable commodities. Food consumption generally still uses plastic and the management use diesel fuel boats for rent, which at least causes water pollution.

8) Control and support development from external parties. The local government helps the local community in managing this tourism area through the assistance of facilities and infrastructure as well as other needs.

9) Empowerment of the local community. This tourism area is managed by local people and brings economic benefits.

\section{Tanjung Tinggi Beach}

Tanjung Tinggi Beach is located in Belitung Regency. It is popular along with the popularity of the Laskar Pelangi film by Andrea Hirata. Tanjung Tinggi Beach is one of the shooting places for Laskar Pelangi. Based on the data as shown in figure 3, Tanjung Tinggi Beach scored 7 from a total of 9 (fulfilled category). Assessed based on the ecotourism principles, the results as follows:

1) Environmental conservation Practices. Although it is a very popular tourist destination, Tanjung Tinggi Beach does not have environmental conservation practices.

2) Encourage tourist's concern for the environment. There are appeals to care and preserve nature and the environment.

3) Attractions that include exploratory environmental experiences. The management provides an exploratory experience for tourists who want to try the challenge, which consists of equipment for snorkeling and boat rentals to explore the coastal area.

4) Green tourism practices by tourism management. There are appeals through signposts to care and preserve the environment, including appeals to dispose of trash in the trash bins.

5) Impact of tourism area development on the environment. The development of Tanjung Tinggi Beach area is not destructive to the environment. But it has been planned to build public facilities in this tourism area.

6) Tourist vulnerability. The management has provided several coast guards and there is also a police post not far from this beach. Managers encourage tourists to look after their children when swimming at the beach.

7) Consumption of non-renewable commodities. There is still a lot of plastic waste found around the beach, as well as the use of diesel fuel for boat rentals.

8) Control and support development from external parties. This beach is managed by a private company.

9) Empowerment of the local community. The local community is still permitted provided that the place of selling is not permanent. A few years before, the beach area was very crowded with various culinary places to eat seafood, but now it is localized to a place further from the beach. The involvement of the local community runs well.

\section{Lengkuas Island}

Lengkuas Island is located in Belitung Regency. Travel time to Lengkuas Island from Tanjung Kelayang Beach is approximately 1 hour by boat. Lengkuas Island is famous for its beautiful coral reefs. Based on the data as shown in figure 3, Lengkuas Island scored 8.25 from a total of 9 (fulfilled category). Assessed based on the ecotourism principles, the results as follows: 
1) Environmental conservation Practices. To maintain conservation, island management makes appeals to tourists and invitations to preserve the island.

2) Encourage tourist's concern for the environment. There are appeals to care and preserve nature and the environment.

3) Attractions that include exploratory environmental experiences. As an island with beautiful coral reefs, explorative experiences are available for tourists through snorkeling in coral reef areas. Lengkuas Island is also home to a rare and varied fish ecosystem.

4) Green tourism practices by tourism management. There is an appeal to keep the island clean. Trash bins are provided in several areas and the island looks clean.

5) Impact of tourism area development on the environment. This island was not built many additional facilities. Releasing the boat anchor while snorkeling is still a problem.

6) Tourist vulnerability. The boat used to reach the island is generally a wooden boat and small size so the chance of accidents may still occur. As anticipation, the management always requires the use of safety buoys while on a boat and avoid traveling during the big wave season.

7) Consumption of non-renewable commodities. The management is still using diesel fuel boats. For cleanliness, tourists are required to collect trash into trash bags that have been provided by the management.

8) Control and support development from external parties. The island is managed by the local community and the role of local government is quite dominant.

9) Empowerment of the local community. Boats and sales are managed by the local community so that direct profits are obtained by the local community.

\section{The Ecotourism Principles Fulfillment in Bangka Belitung}

Based on the survey data, the ecotourism principles fulfillment in Bangka Belitung as follows:

Figure 4

The Ecotourism Principles Fulfillment in Bangka Belitung

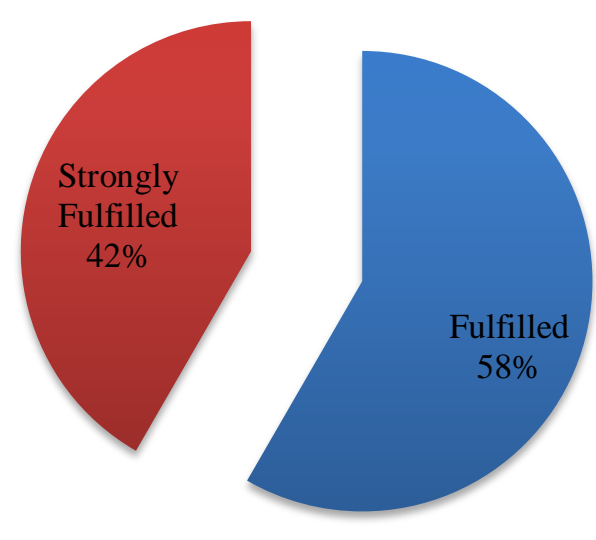

Source: (Primary Data, 2019)

Copyright (C 2019. Owned by Author(s), published by Society. This is an open access article under CC-BY-NC-SA license. 
Based on the data as shown in figure $4,58 \%$ of the tourism areas in Bangka Belitung were included in the category of fulfilled the ecotourism principles and $42 \%$ were in the strongly fulfilled category of ecotourism principles. In Bangka Island, 4 out of 6 tourism destinations are in the fulfilled category and 2 tourism destinations are in the strongly fulfilled category. While in Belitung Island, 3 out of 6 tourism destinations are in the fulfilled category and 3 tourism destinations are in the strongly fulfilled category. None of the tourism areas in Bangka Belitung get a maximum score of 9 as shown in figure 2 and figure 3.

In general, tourism destinations in Bangka Belitung fulfill the ecotourism principles, as the following analysis:

\section{1) Environmental conservation practices}

Conservation is one of the main characteristics of ecotourism. Through conservation, there is awareness to encourage mutual concern to encourage environmental preservation activities. One of the fundamental ideas in the development of ecotourism is the desire to make conservation a joint activity and at the same time make tourists as partners in conservation activities. Although according to Holden (2009: 19-31 in Hill \& Gale, 2009), this is still a matter of debate and also because of its complexity.

Observation results indicate that conservation is still very limited. A total of 12 tourism destinations were observed, only 5 destinations that truly have conservation practices. In conservation activities, tourists should be invited to be part of the conservation process. In several tourism destinations in Bangka Belitung, most are still focused on sea turtle breeding, only a few are focused on replanting trees (greening). The involvement of tourists in conservation activities can be through a variety of ways, for example, the program of one tourist one tree, one tourist one persuasion on social media, or other activities that encourage the active involvement of tourists in conservation practices.

\section{2) Encourage tourists concern for the environment}

The education process for tourists has not run optimally. The education process is only through signposts that contain appeals in some areas, although not all tourist destinations implement it. The management of the tourism area in Bangka Belitung still presupposes that tourists will conclude and draw their wisdom during the tour process. The process for educating tourists has not been planned and has no clear educational concept. It is necessary to develop the principle of edutourism (educational tourism development).

\section{3) Attractions that include exploratory environmental experiences}

Efforts to build an attractive experience for tourists already exist in several tourism destinations in Bangka Belitung, but not all tourism destinations provide attractive and memorable moments as a new experience for tourists. Generally, existing tourism destinations still rely on natural beauty as a product to impress tourists, without creations to add to exploratory challenges. Lengkuas Island is one of the tourism destinations that present a memorable experience because there are snorkeling and beautiful coral reef views. The trip to the island with a small wooden boat becomes interesting and unforgettable.

\section{4) Green tourism practices by tourism management}

In general, tourism destinations that rely on nature will emphasize aspects of cleanliness. Several tourism areas are not optimal in applying the principle of green tourism. Garbage is generally a problem in some tourism areas. 


\section{5) Impact of tourism area development on the environment}

In general, no development of tourism areas is found by damaging the environment. But there are still external threats to tourism areas that rely on the beauty of the beach. Offshore tin mining around several coastal areas is a real threat to the sustainability of the coastal environment. Although there have been several mining conflicts in the coastal areas (Pratama, 2018; Ibrahim et al., 2018; Ibrahim et al., 2019), the fact is that offshore tin mining has not ended yet. An irony, the tourism sector is expected to run optimally but the beauty of the beach is slowly eroded by the threat of silt, mud, and damage to marine life (see Hengky, 2017; Firdaus \& Endah, 2016). Pasir Padi Beach and Tikus Emas Beach are at least two tourist areas that face this sensitive problem.

\section{6) Tourist vulnerability}

Limited guards are a common problem. Transportation is also a fundamental problem of tourism destinations in Bangka Belitung. Tourism destinations are reached by rental vehicles, not public transportation. The fact is that mass transportation is a problem in Bangka Belitung.

\section{7) Consumption of non-renewable commodities}

The use of plastic is common in tourist areas in Bangka Belitung. Dependence on packaged food cannot be avoided. Plastic waste is still found scattered throughout the tourist area even though the management provides adequate trash facilities. The use of diesel as an energy material is still found in some areas.

\section{8) Control and support development from external parties}

The role of local governments in the development of tourism is relatively limited. The local government should be the party that should be involved in providing recreational needs optimally. Local governments will usually hand over the management of tourism areas to the private sector or local community. This means that local government should be able to optimally assist the process of facilitation and tourism development, not just providing road access, transportation and facilitation on the surface, but limited to the substance of ecotourism in managing tourism destinations. However, according to Wardani et al. (2017) coordination between stakeholders is important in developing tourist destinations. Manurung (2002 in Hundloe, 2002) stated that at least the parties that should be involved are the government, the private sector, and the community.

\section{9) Empowerment of the local community}

There is a problem with ownership that has implications for the dimensions of local community empowerment. One important entity in the ecotourism principle is the involvement of the local community and direct benefits for the local community in the process of developing tourism areas. That does not mean that only tourism destinations managed by the local community or the government can only actively involve the local community. More than that, local community empowerment can also be involved by the private sector which manages the tourism area.

Community empowerment should be able to be carried out even though the tourism destination has been managed by the private sector. Nature-based tourism destinations are generally tourism destinations that are not purely the creation of managers. This means the public, at least the local community has an interest in participating in managing this naturebased tourism destination. The principle of partnership would be important to consider, 
according to Nugroho et al. (2018) that engagement with the local community is part of the sustainability of the ecotourism program.

There are no tourism destinations that achieve a maximum score. The highest score is 8.5. Tanjung Kelayang Beach and Lengkuas Island, which have scores above 8, are both in Belitung Island.

\section{Conclusions}

This research found several things regarding the ecotourism principles of fulfillment in Bangka Belitung. There are at least 9 basic ecotourism principles which are examined in detail in each selected tourism destination. This research found that assessed from 5 interval categories of the ecotourism principles fulfillment, 58\% of the tourism areas in Bangka Belitung were included in the category of fulfilled of the ecotourism principles and $42 \%$ were in the strongly fulfilled category of the ecotourism principles, while none of all get the maximum score for the whole principle.

This research also identifies unique and interesting things in the application of each principle. The six ecotourism principles have been implemented well even with a few notes, which consist of 1) Attractions that include exploratory environmental experiences, 2) Green tourism practices by tourism management, 3) Impact of tourism area development on the environment, 4) Tourist vulnerability, 5) Consumption of non-renewable commodities, and 6) Control and support development from external parties. However, the three principles still need strengthening the implementation of the principles, which consist of 1) Environmental Conservation Practices, 2) Encourage tourists concern for the environment, and 3) Empowerment of the local community.

\section{Acknowledgement}

The authors would like to thank the Directorate General of Research Strengthening and Development for funding support and facilities for making this study successful through Basic Research Grant Scheme, the funding year 2019-2021. (Indonesian: Hibah Penelitian Dasar (7/E/PT/2019, 185.A/UN.50.3.1/PP/2019)), awarded by the Ministry of Research, Technology and Higher Education of the Republic of Indonesia.

\section{References}

Bratasida, L. (2002). Green Productivity and Ecotourism in Hundloe, T. (2002). Linking green productivity to ecotourism: Experiences in the Asia-Pacific Region. Tokyo: Asian Productivity Organization.

Badan Pusat Statistik Provinsi Kepulauan Bangka Belitung. (2017). Direktori Hotel Provinsi Kepulauan Bangka Belitung 2017. Pangkalpinang: Badan Pusat Statistik Provinsi Kepulauan Bangka Belitung.

Badan Pusat Statistik Provinsi Kepulauan Bangka Belitung. (2018). Perkembangan Pariwisata dan Transportasi Kepulauan Bangka Belitung April 2018. Pangkalpinang: Badan Pusat Statistik Provinsi Kepulauan Bangka Belitung.

Buckley, R. (1994). A framework for ecotourism. Annals of tourism research, 21(3), 661-665.

Buckley, R. (2009). Ecotourism: Principles and practices. Cambridge: Cambridge University Press. 
Butarbutar, R., \& Soemarno, S. (2013). Environmental effects of ecotourism in Indonesia. Journal of Indonesian Tourism and Development Studies, 1(3), 97-107.

Chairiyah, N. (2013). Taxonomic Contribution For Ecotourism Development In Indonesia. Journal of Indonesian Tourism and Development Studies, 1(3), 115-122.

Dalem, A. (2002). Ecotourism in Indonesia. In Hundloe, T. (2002). Linking green productivity to ecotourism: Experiences in the Asia-Pacific Region. Tokyo: Asian Productivity Organization.

Damanik, J., \& Weber, H. F. (2006). Perencanaan ekowisata dari teori ke aplikasi. Yogyakarta: Pusat Studi Pariwisata Universitas Gadjah Mada.

Erman, E. (2017). Aktor, akses dan politik lingkungan di pertambangan timah Bangka. Masyarakat Indonesia, 36(2), 71-101.

Fandeli, C. (2002). Perencanaan Kepariwisataan Alam. Yogyakarta: Universitas Gadjah Mada.

Firdaus, N., \& Endah, N. H. (2016). Accelerating the Development of Bangka Island through Sustainable Tourism by Strengthening the Roles of Multi-stakeholder. Bisnis \& Birokrasi Journal, 22(3), 169-179.

Hengky, S. H. (2017). Beholding Tanjung Pesona coastal-ecotourism in Bangka Islands, Indonesia. Business and Economic Research, 7(2), 102-117.

Hill, J., \& Gale, T. (2009). Ecotourism and environmental sustainability: Principles and practice. Farnham, England: Ashgate Publishing Limited.

Holden, A. (2008). Environment and Tourism (Second Edition). New York: Routledge.

Hundloe, T. (2002). Linking green productivity to ecotourism: Experiences in the Asia-Pacific Region. Tokyo: Asian Productivity Organization.

Ibrahim, I., Haryadi, D., \& Wahyudin, N. (2018). From charm to sorrow: The dark portrait of tin mining in Bangka Belitung, Indonesia. PEOPLE: International Journal of Social Sciences, $4(1), 360-382$.

Ibrahim, I., Haryadi, D., \& Wahyudin, N. (2018). Local Fisherman Resistance in Kelapa Kampit Coastal Area Toward Offshore Mining Activities. In E3S Web of Conferences (Vol. 47, p. 05003). EDP Sciences.

Ibrahim, I., Zukhri, N., Rendy, R. (2019). Between Natural Tourism, the Booming of Laskar Pelangi Film, and the Image of Environmental Damage: Measuring the Perception of Regional Tourist on Bangka Belitung Tourism. In Journal of Physics: Conference Series (Vol. 1351, No. 1, p. 012107). IOP Publishing.

Ibrahim, I., Haryadi, D., \& Wahyudin, N. (2019). Between Fishing, Mining, and Suction Vessel: The Compromise of Teluk Limau People, West Bangka, On Tin Mining Aggression. PEOPLE: International Journal of Social Sciences, 5(1). 178 - 185.

Nofiarli, N. (2018). The Development of Ecotourism Model at Natural Attractions of Tete Batu Village in East Lombok. Sumatra Journal of Disaster, Geography and Geography Education, 2(1), 184-190.

Nugroho, I., Negara, P. D., \& Yuniar, H. R. (2018). The planning and the development of the ecotourism and tourism village in Indonesia: a policy review. Journal of Socioeconomics and Development, 1(1), 43-51.

Pratama, S. (2018). Dimensi Ekonomi Politik Dalam Konflik Tata Kelola Pertambangan (Studi Kasus Surat Keputusan Gubernur Bangka Belitung Tentang Penghentian Sementara Operasional Pertambangan Laut PT Timah, Tbk Tahun 2016). JWP (Jurnal Wacana Politik), 3(1), 40 - 53. 
Safitri, D., \& Putra, Z. F. F. (2018). Ecotourism of Social Culture Aspect in Indonesia. In Proceeding International Conference on University and Intellectual Culture (Vol. 1, No. 1, pp. 60-71).

Susilo, J., \& Maemunah, S. (2009). Tiga abad melayani dunia: potret tambang timah Bangka Belitung. Jakarta: Jaringan Advokasi Tambang.

Valeriani, D. (2010). Kebijakan Pengembangan Pariwisata di Provinsi Kepulauan Bangka Belitung. EQUITY, 1(4), 1-27.

Wall, G. (1997). Is ecotourism sustainable?. Environmental management, 21(4), 483-491.

Wardani, M. P., Fahrudin, A., \& Yulianda, F. (2017, October). Analysis of successful strategy to develop sustainable marine ecotourism in Gili Bawean Island, Gresik, East Java. In IOP Conference Series: Earth and Environmental Science (Vol. 89, No. 1, p. 012036). IOP Publishing.

Wardhani, R.S., Valeriani, D. (2016). Green Tourism dalam Pengembangan Pariwisata Bangka Belitung. Jurnal Ilmiah Ekonomi Global Masa Kini, 7(1), 24-29.

Wood, M. (2002). Ecotourism: Principles, practices, and policies for sustainability. Paris: United Nations Environment Programme.

\section{About the Authors}

1. Ibrahim, obtained his Doctoral Degree in Philosophy (2012) and in Political Science (2014), both from Gadjah Mada University, Indonesia. The author is an Associate Professor at the Department of Political Science, Faculty of Social and Political Sciences, University of Bangka Belitung, Indonesia.

E-Mail: $\underline{\text { iim_babel@yahoo.com }}$

2. Nizwan Zukhri, obtained his Doctoral Degree in Management from University of Bengkulu, Indonesia, in 2018. The author is an Associate Professor at the Department of Management, Faculty of Economics, University of Bangka Belitung, Indonesia.

E-Mail: nizwan_ubb@yahoo.com

3. Rendy, obtained his Master Degree in Political Science from Gadjah Mada University, Indonesia, in 2012. The author is an Assistant Professor at the Department of Political Science, Faculty of Social and Political Sciences, University of Bangka Belitung, Indonesia. E-Mail: rendyubb@gmail.com 